\title{
COMBINATION OF INTEGRATION ANALYTIC HIERARCHY PROCESS AND GOAL PROGRAMMING FOR MULTI- OBJECTIVE OPTIMIZATION PROMOTION PROGRAM TELECOMMUNICATION SERVICES INDUSTRY
}

\author{
Charlitta Fhilya $^{1}$, Yopi Andry Lesnussa ${ }^{2 *}$, Venn Yan Ishak Ilwaru ${ }^{3}$ \\ ${ }^{1,2,3}$ Department of Mathematics, Pattimura University \\ St. Ir. M. Puttuhena, Kampus Unpatti, Poka, Ambon City, 97233, Province of Maluku, Indonesia
}

Corresponding author e-mail: 2 yopi_a_lesnussa@yahoo.com

\begin{abstract}
In the globalization era, almost everyone uses the telecommunications in everyday life. The dependence on telecommunication service provider forces the service provider industry to expand the network and offer affordable promotions for all levels of the community. Based on that, "PT. Telkom Indonesia Tbk" as one of the Indonesian companies in the telecommunication sector, must have a strategy of promotion in selling Indihome internet products. This research using the Analytic Hierarchy Process to determine weights from many promotion criteria and various alternatives, and then, using Goal Programming to find the minimum cost promotion by choosing alternatives based on the criteria. The result of this research is obtaining eight effective of nine existing promotional program.
\end{abstract}

Keywords: Analytic hierarchy process, Goal programming, Promotion programs.

Article info:

Submitted: $13^{\text {th }}$ October 2020

Accepted: $25^{\text {th }}$ February 2021

How to cite this article:

C. Fhilya, Y. A. Lesnussa, Venn Yan Ishak Ilwaru, "COMBINATION OF INTEGRATION ANALYTIC HIERARCHY PROCESS AND GOAL PROGRAMMING FOR MULTI-OBJECTIVE OPTIMIZATION PROMOTION PROGRAM TELECOMMUNICATION SERVICES INDUSTRY", BAREKENG: J. Il. Mat. \& Ter., vol. 15, no. 1, pp. 059-068, Mar. 2021.

\section{(†) (อ)}

This work is licensed under a Creative Commons Attribution-ShareAlike 4.0 International License.

Copyright () 2021 Charlitta Fhilya, Yopi Andry Lesnussa, Venn Yan Ishak Ilwaru, 


\section{INTRODUCTION}

The service industry is one of the fastest-growing industries in Indonesia. According to Kotler and Armstrong, the service industry is an industry that produces a form of product that is intangible and does not produce ownership of something[1]. Today almost everyone uses the telecommunications service [2]. Existing telecommunications services include mobile telephone services, cellular telephone services, interconnection services, short message services, fax services, cellular internet services, and video calls[3]. PT. Telkom Indonesia Tbk., is a state company engaged in providing telecommunications services with the largest network in Indonesia. As one of the telecommunications industry, PT. Telkom has an internet product called IndiHome. With a speed of $100 \mathrm{Mbps}$, it is believed that IndiHome will become the people's choice as a broadband service[4].To improve their service, PT. Telkom as the telecommunications companies must uphold the quality of their services and change the core marketing strategy [5]. It is important for PT. Telkom to identify service factors that affect customer loyalty, even prospective customers. From the promotion costs limit and a variety of alternatives program promotion, and also many desired promotion criteria, we can form a model to determine effective promotion programs using the combination of the Analytic Hierarchy Process method and Goal Programming[6]. The Analytic Hierarchy Process methods are using to determine weights priority. While the Goal Programming methods are using to optimize the cost promotion.

Analytic Hierarchy Process (AHP) is a multi-criteria decision-making method that has been widely used in almost all applications related to decision making[7][8]. The specialty of AHP is because this method is flexible to be integrated with different methods such as Goal Programming [9]. The combination of these two methods is widely used for optimization which has traditionally been valid in the financial literature [10]. By using each other's advantages to cover up the weaknesses of this method, it will produce an optimal solution[11][12]. Therefore, the purpose of this study is to obtain a Goal Programming model by integrating the weights obtained from the Analytic Hierarchy Process method, and applying the model to develop an effective promotional strategy for PT. Telkom Indonesia Tbk, Ambon.

\section{METHOD}

The quantitative data used in this research are obtained from observations and direct interviews with the Head of Promotion of PT. Telkom Indonesia Tbk., Ambon. The qualitative data is regarding the assessment priority of pairwise comparison based on promotion criteria and alternative promotions [23]. While the quantitative data is the allocation of resources owned like funds, time, and the number of promotional workers. Both of the data will be processed using the Analytic Hierarchy Process (AHP) and Goal Programming methods. AHP is a comprehensive decision-making model that takes into account qualitative and quantitative matters [15]. The Goal Programming method is an extension of the Linear Programming method which has many objective functions. Goal Programming aims to minimize deviations or risks from certain achievement goals by considering hierarchical priorities [24].

The determination of weight with AHP method begins with the hierarchical structure from general objectives, promotional criteria, and alternative promotional programs[13]. The weight obtained using the AHP method is the result of the normalization process of pairwise comparison matrices that have been tested for consistency based on the value of Consistency Ratio (CR) with a tolerance of 10\% [14][15].

Then the weight is used as the coefficient of formulation of the Goal Programming model based on the problems discussed and resolved using Software[16][17]. The results produced will be an optimal promotion program strategy with sensitivity analysis to ensure the determination of the model formed by changes in promotional funds owned[18]. 


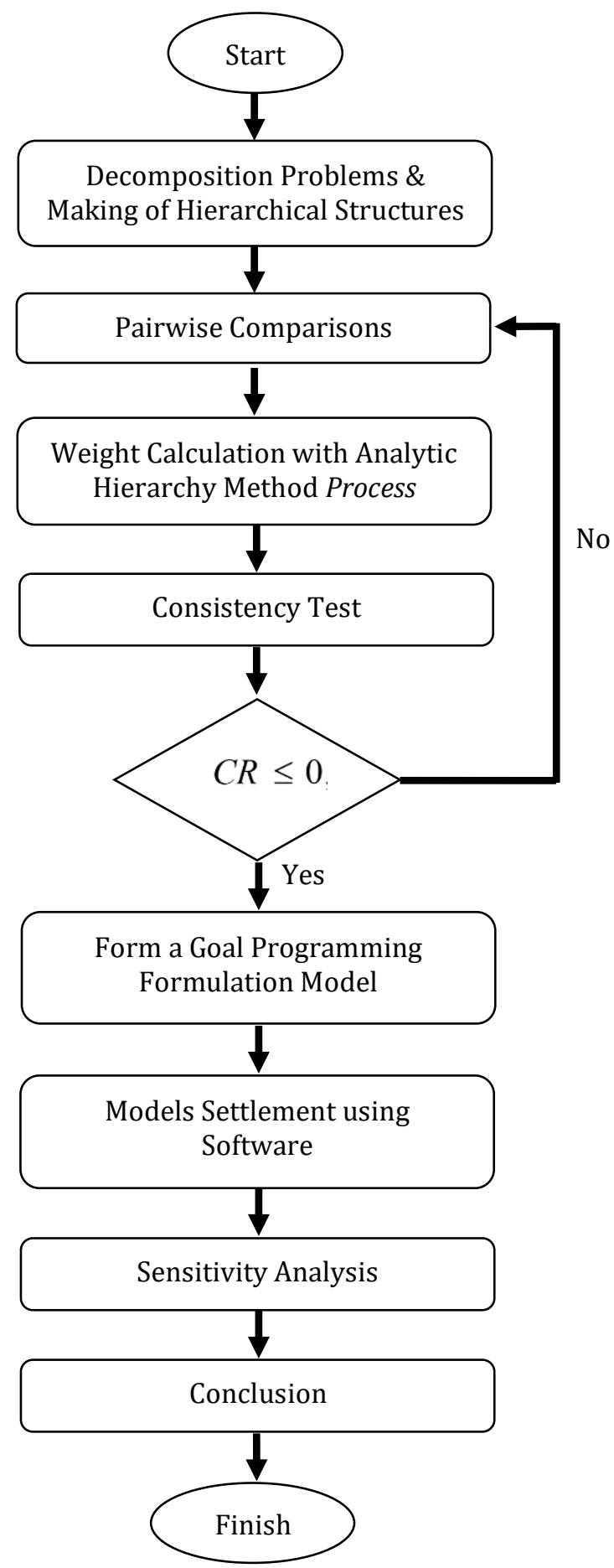

Figure 1. Data Analysis Flow Chart

\section{RESULTS AND DISCUSSION}

The purpose of this research is to obtain the selected promotional programs that will be used as marketing strategies by PT. Telkom Indonesia Tbk., Ambon in getting new prospective customers. The Promotional programs formed are promotions that are attractive, informative, communicative, persuasive, and memorable. Based on these criteria, PT. Telkom Indonesia Tbk Ambon has 9 promotional programs along with promotional costs which can be seen in Table 1. As well as the resources owned by PT. Telkom Indonesia Tbk., Ambon for promotional programs can be seen in Table 2. 
Table 1. Promotional Programs Cost Allocation

\begin{tabular}{lr}
\hline Alternative Promotion Program & $\begin{array}{c}\text { Promotions Cost } \\
\text { (Rp.) }\end{array}$ \\
\hline “Add lips"advertisement on Radio $\left(\mathrm{X}_{1}\right)$ & 20.000 .000 \\
\hline Advertising in Newspapers $\left(\mathrm{X}_{2}\right)$ & 10.000 .000 \\
\hline Bill boards Instalments $\left(\mathrm{X}_{3}\right)$ & 4.000 .000 \\
\hline Promotion with Banners $\left(\mathrm{X}_{4}\right)$ & 50.250 .000 \\
\hline Door To Door Marketing $\left(\mathrm{X}_{5}\right)$ & 50.000 .000 \\
\hline Open Table $\left(\mathrm{X}_{6}\right)$ & 50.000 .000 \\
\hline Festival $\left(\mathrm{X}_{7}\right)$ & 50.000 .000 \\
\hline Website Promotion $\left(\mathrm{X}_{8}\right)$ & 0 \\
\hline Promotion on Radio $\left(\mathrm{X}_{9}\right)$ & 0 \\
\hline \multicolumn{2}{c}{ Total Promotion Costs } \\
\hline
\end{tabular}

Table 2. Promotional Resources of PT. Telkom Indonesia Tbk Ambon

\begin{tabular}{lc}
\hline \multicolumn{1}{c}{ Resources } & $\begin{array}{c}\text { Allocation for } \\
\text { Promotion } \\
\text { Programs }\end{array}$ \\
\hline Promotion Cost & Rp. $200.000 .000,-$ \\
\hline Promotion Time & 252 days \\
\hline Promotion Worker & 35 Person \\
\hline
\end{tabular}

The problem is arranged in a hierarchical structure with the relation of each level of the hierarchy which can be seen in Figure 2.

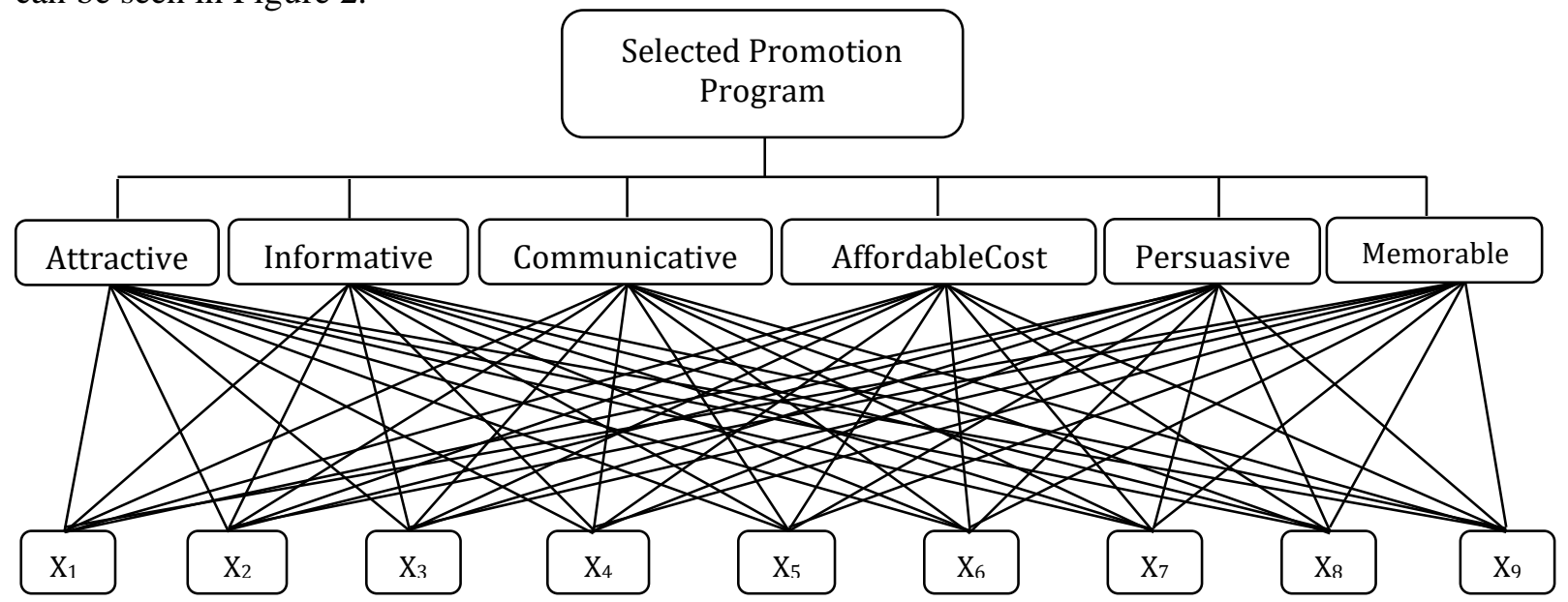

Figure 2. Hierarchical Structure for Promotion Program Analysis

\subsection{Weighting With AHP Method}

Using the relevance between each of the hierarchies, a pairwise comparison of each criterion, and each alternative based on the criteria[19][20]. Through the AHP calculation process with the Comparative Judgment principle, the results obtained are the priority weights for each criterion in Table 3 and alternative priority weights for each criterion in Table 4[21]. 
Table 3.Weights Priority Criteria

\begin{tabular}{ll}
\hline \multicolumn{1}{c}{ Criteria } & Weight \\
\hline Attractive & 0,332 \\
\hline Informative & 0,108 \\
\hline Communicative & 0,184 \\
\hline Affordable Cost & 0,209 \\
\hline Persuasive & 0,027 \\
\hline Reminder & 0,140 \\
\hline
\end{tabular}

Table 4.Weight of Alternative Priorities against Criteria

\begin{tabular}{|c|c|c|c|c|c|c|}
\hline \multirow[b]{2}{*}{ Alternative } & \multicolumn{6}{|c|}{ Criteria } \\
\hline & 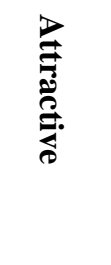 & 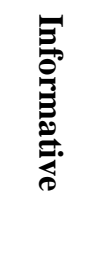 & 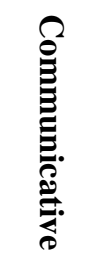 & 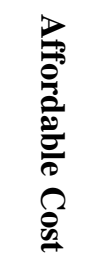 & 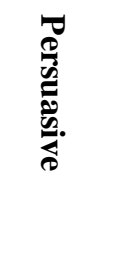 & $\begin{array}{l}\frac{3}{0} \\
\frac{0}{0} \\
\frac{0}{0} \\
\frac{0}{0}\end{array}$ \\
\hline $\mathrm{X}_{1}$ & 0,143 & 0,130 & 0,136 & 0,054 & 0,061 & 0,086 \\
\hline $\mathrm{X}_{2}$ & 0,041 & 0,098 & 0,026 & 0,054 & 0,077 & 0,068 \\
\hline $\mathrm{X}_{3}$ & 0,026 & 0,069 & 0,029 & 0,149 & 0,100 & 0,234 \\
\hline $\mathrm{X}_{4}$ & 0,039 & 0,081 & 0,042 & 0,054 & 0,100 & 0,150 \\
\hline $\mathrm{X}_{5}$ & 0,183 & 0,098 & 0,152 & 0,074 & 0,153 & 0,073 \\
\hline $\mathrm{X}_{6}$ & 0,183 & 0,081 & 0,180 & 0,041 & 0,197 & 0,073 \\
\hline$X_{7}$ & 0,183 & 0,081 & 0,237 & 0,041 & 0,189 & 0,073 \\
\hline $\mathrm{X}_{8}$ & 0,039 & 0,098 & 0,039 & 0,288 & 0,060 & 0,136 \\
\hline $\mathrm{X}_{9}$ & 0,163 & 0,263 & 0,159 & 0,244 & 0,063 & 0,108 \\
\hline
\end{tabular}

The priority weight's consistency has been tested, with the maximum eigenvalues obtained and the value of the Consistency Index (CI) obtained from the equation[22]:

$$
C I=\frac{\lambda_{\max }-n}{n-1}
$$

The CI value is compared with the value of the Random Index (RI) which produces the Consistency Ratio (CR) value as follows:

1) Assessment for all criteria, $\mathrm{CR}=0,083$

2) Alternative assessments based on attractive criteria, $\mathrm{CR}=0,089$

3) Alternative assessments based on informative criteria, $\mathrm{CR}=0,090$

4) Alternative assessments based on communicative criteria, $\mathrm{CR}=0,093$

5) Alternative assessments based on affordable criteria, $C R=0,091$

6) Alternative assessments based on persuasive criteria, $\mathrm{CR}=0,087$

7) Alternative assessments based on memorable criteria, $\mathrm{CR}=0,093$ 


\subsection{Formulation of The Goal Programming Model}

\section{a. Decision Variables}

The decision variables in this study are selected promotion programs of PT. Telkom Indonesia Tbk. Ambon, stated by $X_{i}$ for $i=1,2, . ., 9$.

\section{b. Objective Constraints}

Minimize Promotion Costs

$$
\begin{aligned}
& \sum_{i=1}^{9} A X_{i}+d_{1}^{-}-d_{1}^{+}=200000000 \\
& \min Z=d_{1}^{+}
\end{aligned}
$$

Maximizing the Election of Attractive Promotion Programs

$$
\begin{aligned}
& \sum_{i=1}^{9} B X_{i}+d_{2}^{-}-d_{2}^{+}=1 \\
& \min Z=d_{2}^{-}
\end{aligned}
$$

Maximizing the Election of Informative Promotion Programs

$$
\sum_{i=1}^{9} C X_{i}+d_{3}^{-}-d_{3}^{+}=1
$$

$\min Z=d_{3}^{-}$

Maximizing the Election of Communicative Promotion Programs

$$
\sum_{i=1}^{9} D X_{i}+d_{4}^{-}-d_{4}^{+}=1
$$

$\min Z=d_{4}^{-}$

Maximizing the Election of Affordable Promotion Programs

$$
\begin{aligned}
& \sum_{i=1}^{9} E X_{i}+d_{5}^{-}-d_{5}^{+}=1 \\
& \min Z=d_{5}^{-}
\end{aligned}
$$

Maximizing the Election of Persuasive Promotion Programs

$$
\begin{aligned}
& \sum_{i=1}^{9} F X_{i}+d_{6}^{-}-d_{6}^{+}=1 \\
& \min Z=d_{6}^{-}
\end{aligned}
$$

Maximizing the Election of Memorable Promotion Programs

$$
\begin{aligned}
& \sum_{i=1}^{9} G X_{i}+d_{7}^{-}-d_{7}^{+}=1 \\
& \min Z=d_{7}^{-}
\end{aligned}
$$

Notes:

$A$ : Promotion Cost Allocation for each alternative

$B$ : The priority weights of each alternative against attractive criteria

$C$ : The priority weights of each alternative against informative criteria

$D$ : The priority weights of each alternative against communicative criteria

$E \quad$ : The priority weights of each alternative against affordable criteria

$F \quad$ : The priority weights of each alternative against persuasive criteria

$G$ : The priority weights of each alternative against memorable criteria

$d_{i}^{-}$: Negative deviation variables 
$d_{i}^{+}:$Positive deviation variables

\section{c. Objective Function}

The objective function of these problems is to minimize the deviation with the formulation as follows: $\min Z=d_{1}^{+}+d_{2}^{-}+d_{3}^{-}+d_{4}^{-}+d_{5}^{-}+d_{6}^{-}+d_{7}^{-}$

\subsection{Settlement With Sofware}

Furthermore, the model is solved with the help of software, namely LINGO Version 17.0. So the results of the selection of promotional programs for PT. Telkom Indonesia Tbk Ambon can be seen in Table 5.

Table 5. Results of Completion of the Goal Programming Model

\begin{tabular}{llcc}
\hline \multicolumn{1}{c}{ Alternative } & $\begin{array}{c}\text { Decision } \\
\text { Variables }\end{array}$ & Value & $\begin{array}{c}\text { Promotions Cost } \\
\text { (Rp) }\end{array}$ \\
\hline Advertisement "add lips" on Radio $\left(\mathrm{X}_{1}\right)$ & $\mathrm{X}_{1}$ & 1,0000 & 20.000 .000 \\
\hline Advertising in Newspapers $\left(\mathrm{X}_{2}\right)$ & $\mathrm{X}_{2}$ & 1,0000 & 10.000 .000 \\
\hline Install Billboards $\left(\mathrm{X}_{3}\right)$ & $\mathrm{X}_{3}$ & 1,0000 & 4.000 .000 \\
\hline Promotion with Banners $\left(\mathrm{X}_{4}\right)$ & $\mathrm{X}_{4}$ & 0,0000 & 50.250 .000 \\
\hline Door To Door Marketing $\left(\mathrm{X}_{5}\right)$ & $\mathrm{X}_{5}$ & 1,0000 & 50.000 .000 \\
\hline Open Table $\left(\mathrm{X}_{6}\right)$ & $\mathrm{X}_{6}$ & 1,0000 & 50.000 .000 \\
\hline Festival $\left(\mathrm{X}_{7}\right)$ & $\mathrm{X}_{7}$ & 1,0000 & 50.000 .000 \\
\hline Website Promotion $\left(\mathrm{X}_{8}\right)$ & $\mathrm{X}_{8}$ & 1,0000 & 0 \\
\hline Promotion on Radio $\left(\mathrm{X}_{9}\right)$ & $\mathrm{X}_{9}$ & 1,0000 & 0 \\
\hline
\end{tabular}

Table 5 explains that the promotion program $X_{i}=1$ indicates selected and $X_{i}=0$ indicates not selected. Based on this, promotion programs that are not selected are Promotions with Banners (X4), so that promotional programs are planned for PT. Telkom Indonesia Tbk Ambon there are 8 promotion programs with the costs used are Rp. 184.000.000, - and the remaining unused promotional costs of Rp. 16.000.000.

\subsection{Sensitivity Analysis}

The results of the solution from the developed model are strongly influenced by the determination of constraints, goals, objectives and weighting of AHP integration in the model. Therefore, a sensitivity analysis is needed to test the model by varying the changes in the number of promotional costs available, like the following Table 6 . 
Table 6. Sensitivity Analysis with Promotional Cost Changes

\begin{tabular}{cclc}
\hline \multirow{2}{*}{$\begin{array}{c}\text { Promotion Cost } \\
\text { (Rp.) }\end{array}$} & $\begin{array}{c}\text { Promotion Cost } \\
\text { Change } \\
\text { Percentage } \\
\end{array}$ & Unselected Promotion Program & $\begin{array}{c}\text { Ibjective } \\
\text { Promotion Cost } \\
(\text { Rp. })\end{array}$ \\
\cline { 3 - 4 } & -15 & $\begin{array}{l}\text { "Add lips" ads on Radio }\left(\mathrm{X}_{1}\right) \\
\text { Promotion with Banners }\left(\mathrm{X}_{4}\right)\end{array}$ & 164.000 .000 \\
\hline 170.000 .000 & -10 & $\begin{array}{l}\text { Ads in Newspapers }\left(\mathrm{X}_{2}\right) \\
\text { Promotion with Banners }\left(\mathrm{X}_{4}\right)\end{array}$ & 174.000 .000 \\
\hline 180.000 .000 & -5 & Promotion with Banners $\left(\mathrm{X}_{4}\right)$ & 184.000 .000 \\
\hline 190.000 .000 & 0 & Promotion with Banners $\left(\mathrm{X}_{4}\right)$ & 184.000 .000 \\
\hline 200.000 .000 & 5 & Promotion with Banners $\left(\mathrm{X}_{4}\right)$ & 184.000 .000 \\
\hline 210.000 .000 & 10 & Promotion with Banners $\left(\mathrm{X}_{4}\right)$ & 184.000 .000 \\
\hline 220.000 .000 & 15 & Ads in Newspapers $\left(\mathrm{X}_{2}\right)$ & 224.000 .000 \\
\hline 230.000 .000 & & &
\end{tabular}

The results of the sensitivity analysis indicated that there is a stable solution if the cost of sale fell below 5\% and rising as much as $5 \%$ and $10 \%$, which is a program that is not selected namely Banner Promotions (X4).

\section{CONCLUSIONS}

The Goal Programming model obtained shows the influence of the weight obtained from the AHP method so that based on available promotional costs, the model eliminates one promotional program, namely variable X4 (Promotion with Benners) and the objective cost used Rp. 184.000.000,-.

\section{REFERENCES}

[1] P. Kotler and G. Armstrong, Principles of Marketing 15. 2013.

[2] M. Dachyar and M. Noviannei, "Customer Satisfaction Index Telecommunication Industry in Indonesia," World Acad. Sci. Eng. Technol., 2012.

[3] N. J. Suchy, "Influence of Customer Satisfaction on Loyalty : a Study on,” J. Soc. Sci., vol. 9, no. 2, pp. 73-80, 2013.

[4] T. Umbara and M. Ariyanti, "The Effect Of Customer Relationship Management To Speedy/Indihome Customer Loyalty And Strategic Implementation In Telkom E-Service," in Proceedings of the 3rd International Seminar and Conference on Learning Organization (isclo-15), 2016.

[5] Y. H. Yuan, W. Zhang, S. Britt, and A. Ronneby, "How to Promote Customer Loyalty of Chinese Mobile Telecom Operator: Case Study of China Mobile," no. June, 2009.

[6] R. Al-Husain and R. Khorramshahgol, "Incorporating analytical hierarchy process and goal programming to design responsive and efficient supply chains," Oper. Res. Perspect., 2020.

[7] A. Ishizaka and A. Labib, "Review of the main developments in the analytic hierarchy process," Expert Syst. Appl., May 2011.

[8] Z. Srdevic, B. Blagojevic, and B. Srdevic, "AHP based group decision making in ranking loan applicants for purchasing irrigation equipment: A case study," Bulg. J. Agric. Sci., 2011.

[9] M. Bertolini and M. Bevilacqua, "A combined goal programming-AHP approach to maintenance selection problem," Reliab. Eng. Syst. Saf., vol. 91, no. 7, pp. 839-848, Jul. 2006.

[10] N. S. Arunraj and J. Maiti, "Risk-based maintenance policy selection using AHP and goal programming," Saf. Sci., vol. 48, no. 2, pp. 238-247, Feb. 2010.

[11] E. C. Özcan, S. Ünlüsoy, and T. Eren, "A combined goal programming - AHP approach supported with TOPSIS for maintenance strategy selection in hydroelectric power plants,” Renew. Sustain. Energy Rev., vol. 78, pp. 1410-1423, Oct. 2017.

[12] H. P. Ho, C. Ter Chang, and C. Y. Ku, "On the location selection problem using analytic hierarchy process and multichoice goal programming,” Int. J. Syst. Sci., 2013.

[13] J. Khazaii and J. Khazaii, "Analytical Hierarchy Process (AHP)," in Advanced Decision Making for HVAC Engineers, 2016.

[14] M. J. Liberatore and R. L. Nydick, "The analytic hierarchy process in medical and health care decision making: A 
literature review," Eur. J. Oper. Res., 2008.

[15] T. L. Saaty, "Decision making with the analytic hierarchy process," Int. J. Serv. Sci., 2008.

[16] F. de Oliveira, N. M. P. Volpi, and C. R. Sanquetta, "Goal programming in a planning problem,” Appl. Math. Comput., vol. 140, no. 1, pp. 165-178, Jul. 2003.

[17] B. Aouni and O. Kettani, "Goal programming model: A glorious history and a promising future," Eur. J. Oper. Res., vol. 133, no. 2, pp. 225-231, Jan. 2001.

[18] E. Borgonovo and E. Plischke, "Sensitivity analysis: A review of recent advances," European Journal of Operational Research. 2016.

[19] A. Labib, "Introduction to the Analytic Hierarchy Process," in Learning from Failures, Elsevier, 2014, pp. 33-44.

[20] A. Emrouznejad and M. Marra, "The state of the art development of AHP (1979-2017): a literature review with a social network analysis," Int. J. Prod. Res., vol. 55, no. 22, pp. 6653-6675, Nov. 2017.

[21] a Görener, "Comparing AHP and ANP: An Application of Strategic Decisions Making in a Manufacturing Company," Int. J. Bus. Soc. Sci., 2012.

[22] T. L. Saaty, "How to make a decision: The analytic hierarchy process," Eur. J. Oper. Res., 1990.

[23] C. Fhilya, Y. A. Lesnussa, V. Y. I. Ilwaru, "Determination of Marketing Strategies on Telecommunication Industry Using Analytic Hierarchy Process (AHP)," IOP Conf. Series: Journal of Physics Conf. Series, 1463 (2020) 012001, 2020.

[24] S. Mulyono.,”Operations Research,” Jakarta: Fakultas Ekonomi Universitas Indonesia, 1991. 
